\title{
Educational financing and improvement: conceptual issues and policy debates in the UK
}

\section{Carol Campbell, Vincent Carpentier and Geoff Whitty}

This paper explores the ways in which education funding questions relate to key policy issues facing contemporary governments. It demonstrates how decisions about the level and distribution of expenditure have different implications for national education systems, institutions and students. Following a general discussion of social investment in education, the paper identifies some specific policy considerations in recent attempts to improve the compulsory and post-compulsory sectors. Drawing in particular on British experience, the impact of decisions about expenditure and funding mechanisms on access and performance is considered. We conclude that funding issues cannot be resolved in purely technical terms, but are contingent upon ideological perspectives about broader economic and social priorities.

\section{Introduction}

Questions concerning education finance are important to debates for policy scholars and policy makers seeking to understand and evaluate the contribution of funding, directly or indirectly, to educational improvements for individuals and for the economy and society. In this introductory overview, we approach this question of funding modalities from a policy perspective with a concern to evaluate the implications for educational systems, institutions and students. We are concerned not only with economic questions of efficiency and effectiveness, but also with processes and outcomes in terms of educational improvements and equity considerations.

The purpose of this article is not to provide a review of the economics of education, but rather to draw on this field to explore policy debates concerning funding and educational improvement. As Grao and Mora (2000, 2) comment:

The bid for a better understanding between economists and educationists is not only an intellectual matter. The true reason is more important. We need to understand both fields for a very practical reason: approaching the points of view of both groups is the best way to be effective in improving education. If the social 
goal of all types of scientists is to improve the welfare of human beings, economists of education and educationists have a more concrete social goal; defining and recommending the best policies and implementing the best practices for improving education because they know that this is a powerful way of improving the welfare of individuals and societies.

Our starting point is that education matters and that government and individual investment in education is significant to ensuring the basic right of access to education and to supporting outcomes in terms of economic, social and individual returns. This recognition of the returns accrued from education has resulted in the allocation of public expenditure to support educational expansion. However, alongside public investment in education, there are policy and economic concerns about the financial costs of maintaining large-scale public provision. Such concerns have taken different forms for compulsory and post-compulsory sectors and in different national contexts, with implications for policy choices concerning funding mechanisms to support educational development. For compulsory education, attention has focused on ensuring efficiencies from funding mechanisms within the education system, in order to maximise educational outcomes from resource inputs. This has been associated with a shift from supplydriven to demand-side funding mechanisms. For post-compulsory education, debate has focused on the balance between public and private investment and returns and the nature of funding mechanism required to balance expanding the quantity of provision, through access measures, with meeting the costs of also providing high quality provision and outputs to meet economic needs. Debates concerning funding mechanisms and educational improvement, therefore, include policy concerns about access to education and outcomes achieved, the quantity and quality of provision, and the need to achieve an education system which is both equitable and efficient.

We draw on sources and information from a range of countries. However our main focus is on perspectives and experiences applicable to the UK, and in particular England. Many of the trends affecting the UK, and policy responses applied, are not unique. Nevertheless there is evidence to suggest that the economic issues associated with educational expansion in the post-World War II period have been felt acutely in the UK, with policy concerns since 1973 focusing on public expenditure levels and funding mechanisms for education (see Carpentier, 2001a, 2003). The key policy debates contained within our overview are closely associated with the central topics in the field of economics of education, as identified by Groa and Mora (2000) 1 .

While we focus in this article on educational expenditure and funding mechanisms, it is recognised that educational improvement is affected by a wide range of factors relating to institutions (e.g. management and leadership), classrooms (curriculum, teaching and learning), individual learners and the context in which educational institutions are based (e.g. socio-economic characteristics). 
From a policy perspective, there can be limitations to attempts to clearly differentiate and evaluate educational expenditure and funding mechanisms at a systemic level from funding inputs, resource decisions, educational processes and outcomes for institutions and individuals. Furthermore, funding changes are frequently combined with wider educational reforms, which make it difficult to evaluate the impact of modes of funding, in practice, in isolation.

\section{Investing in Education for Economic and Social Benefits}

Expenditure to support access to, and provision of, education has been associated with debates about the purposes and contributions of education for individuals, the economy and society. The expansion of educational provision has been associated with economic arguments concerning human capital theory, particularly from the late 1950s onwards. Applying economic models to education, human capital theory considers participation in, and expenditure for, education as an investment for individuals and societies. It is proposed that decisions to invest in education can bring about economic benefits for individuals, for example through enhanced employment and earnings, and in turn for the economy at large, through a skilled, educated and productive workforce (Becker, 1962; Hartog, 2000; Mincer, 1958). At the macroeconomic level, human capital can be considered alongside physical capital as a strategic asset for economic growth in supplying a skilled workforce and supporting knowledge development for improving productivity, for example through technological improvements (Denison, 1967; Schultz, 1961). In the 1980s, the new growth theory proposed that education was the main driving force of economic growth (Lucas, 1988; Romer 1990).

The compulsory years of schooling are significant for future economic and life chances. Patrinos (2000) summarizes that the economic returns for primary and secondary education are at or above $10 \%$ a year (see also Cohn \& Addison, 1998; Psacharopoulos, 1994; Psacharopoulos \& Patrinos, 2002). In particular, ensuring access to, and funding for, «basic education» is vital. As the World Bank's (1995) Priorities and Strategies for Education propose: "A more efficient, equitable, and sustainable allocation of new public investment on education would do much to meet the challenges that education systems face today. Efficiency is achieved by making public investments where they will yield the highest returns - usually, for education investments, in basic education». In «developing» countries, the importance of reducing levels of illiteracy has been strongly promoted. Drawing on the National Child Development Study (NDCS) in the UK and research in the USA, Wolf (2002, p. 34) comments: «Poor literacy and poor numeracy - especially the latter - have a devastating effect on people's chances of well-paid and stable employment». Such findings have been central to 
national initiatives in England such as the literacy and numeracy strategies in all primary schools and targeted initiatives to support individuals, such as Reading Recovery which has extended across a range of countries (Sammons, 2002; Vignoles et al., 2000).

Evidence indicates also that length of education beyond the compulsory stages is positively associated with enhanced income and economic returns for individuals (see for example, OECD/UNESCO, 2003; Psacharopoulos \& Patrinos, 2002). There is a growing income divide between individuals with formal qualifications, particularly post-school, and those without. In short, «every year you stay in education beyond the school-leaving age appears to boost your income significantly» (Wolf, 2002, p. 23). Higher levels of education are associated also with reduced levels of unemployment. In the UK, the economic rates of return associated with higher education are larger than in other OECD countries (see OECD, 2002), with those achieving higher education qualifications earning, on average, 50\% more than non-graduates (see DfES, 2003). This income differential continues to apply even when the number of participants in education post-school has increased significantly over the past 20 years - currently accounting for $43 \%$ participation overall of 18-30 year olds in England (see DfES, 2003). This linkage between length of education and economic outcomes has been a driving factor in the expansion of post-compulsory education.

In terms of an economic cost-benefit calculation, Wolf (2002) queries whether educational expansion beyond ensuring education in the «basics» (reading, writing, mathematics for example) during school years and targeted funding for research and innovation in post-compulsory education to support economic growth is strictly necessary for the economy as a whole. However, such interpretations take little account of the other benefits accrued from education for individuals and society in general. For policy debates about investment in education, it is important therefore to take account of the benefits associated with education that are not primarily economic. These have been referred to as the "wider benefits» (HEFCE, 2001) and the «non-monetary benefits (NMB)» (Vila, 2000) of education which encompass personal and social developments. Although such returns are difficult to measure (see Mingat \& Tan, 1996), Grao \& Mora (2000, p. 3) propose that «Rough estimates conclude that the indirect economic benefits of education (non-monetary benefits) are as important as the direct benefits (monetary benefits)».

In an overview of the research evidence, Vila (2000) explains that private (or internal) NMBs are those benefits for individuals (and potentially their families) accrued from their participation in education. These private benefits have a longitudinal dimension. "Consumption benefits» are associated with direct participation in education, for example attendance at school, while «investment returns» are outcomes from acquiring education, for example following graduation. Vila (2000, p. 24-25) outlines the following NMBs, which are primarily private benefits: 
- Capacity to make informed lifestyle choices.

- Improved health benefits.

- Fertility benefits - choices about conception and family size.

- Benefits of level of parental education for children's educational, economic and health opportunities.

- Occupational choices and benefits.

- Benefits related to consumptions and savings - influence over consumer choices and approach to saving and spending.

These can also have wider benefits for family, friends and society. For example, health benefits are associated with societal improvements and economic benefits, as investment in education could contribute to a reduction in expenditure on aspects of health provision. Vila (2000) highlights also social (or external) benefits, i.e. those that cannot be appropriated only by an individual. These include the contribution of knowledge development to social and economic development, the learning and supporting of social values and norms, reduced criminal behaviour, increased civic responsibility, political participation and the potential for enhanced social cohesion. Such findings support the existence of «externalities», whereby the benefits of education are widespread and non-excludable (see for example Mingat \& Tan, 1996).

Research in England has indicated, in particular, the wider benefits associated with participation in higher education (HEFCE, 2001). For individuals these benefits include the nature and length of employment, continuing improvements in skills, improved physical and mental health, increased civic engagement and promotion of egalitarian social attitudes. The HEFCE report (2001) argues that the "wider benefits» of higher education include generating social capital between individuals which may strengthen social cohesion through support for democratic principles and social values. Therefore, the argument follows that the social benefits of higher education extend from those individuals who directly receive higher education to the society in which they participate.

However, as Mingat and Tan's (1996) evaluation of the overall returns from investment indicates there are variations between sectors of provision for countries at different stages of economic and educational development. Overall, investment in primary education yields the highest returns. Nevertheless, for targeting further investment in education, Mingat and Tan (1996, p.1) suggest that, alongside the general social profitability of investing in education, "primary education is most socially profitable in low-income countries, but its position is replaced by secondary and higher education, respectively in middle- and highincome countries».

Therefore, within the overall patterns of returns for investment in education, variations exist in practice. For example, international variations have been identified (see Cohn \& Addison, 1988; Fontvieille \& Michel, 2002; Psacharopoulos, 1993; Psacharopoulos and Patrinos, 2002; Wolf, 2002). In the OECD and UN- 
ESCO (2003) report, Financing Education - Investments and Returns, of the countries studied, those in Latin America displayed the largest variations in income by educational attainment, while the countries in Asia reflected the least variation. Within countries, there are also variations associated with subject choice, institution of study and characteristics of the individual, particularly their socio-economic background and gender (see for example Conlon \& Chevalier, 2002; Psacharopoulos and Patrinos, 2002).

Overall, there is strong evidence indicating the importance of investment in education to support economic and social returns and this has been used as a basis to support governmental involvement in funding education systems. Public expenditure to support educational expansion has also been given particular force by the recognition of access to education as a basic human right, for example as enshrined in United Nation's Declaration of Human Rights in 1948. However, the recognition that the benefits of education can be both "private», i.e. accrued by the individual, or "public», in the sense that benefits extend beyond individuals and are non-excludable (see Barr, 1993; Heald, 1983) has raised policy and economic debates about the balance between the financial investment in education from public, government sources compared to from private sources. Support for continued public expenditure for education, particularly for universal compulsory provision (see Barr, 2003), includes the existence of "externalities» associated with education (see Mishra, 1984), where the wider social and economic benefits accrued are significant. There are also concerns about potential for «market failures» (see George \& Wilding, 1994 for example) if education were entirely privatised resulting in some individuals, particularly those already experiencing disadvantage, not receiving appropriate educational opportunities. As Psacharopoulos and Patrinos (2002) have commented, economic concerns about the returns from education, therefore, need to take account also of equity and social concerns about the distribution of educational access, opportunities and outcomes (see also López et al., 1998).

In the next section, we outline the development of public expenditure for education associated with supporting increased access and quality of provision, with particular reference to economic and policy developments in the UK.

\section{Developments in Educational Expenditure}

The expansion of educational access internationally has been associated with investment of public expenditure to support educational improvement. Over time, public expenditure has fluctuated in relation to economic developments and educational policies, as discussed below in the case of the UK, with shifting concerns about the level of investment, the distribution of such investment and the efficiencies achieved. 
Although there is private investment and provision of education in the UK, publicly financed education (through taxation and government grant) accounts for more than $90 \%$ of educational expenditure and enrolments (see Carpentier, 2003). From a historical perspective, public investment in UK education increased dramatically between the early 19th century to the end of the 20th century - with an average annual growth rate of $8.1 \%$ between 1833 and 1999 based on current price comparisons. Public expenditure on education2 has increased significantly as a share of Gross Domestic Product (GDP) - from $0.01 \%$ of GDP in 1833 to $4.31 \%$ in 1999 . This growth can be associated with expanded access to education - with only 5\% of the 5-24 year age group in education in 1854 , compared to $85 \%$ in 1996 . Increasing expenditure per pupil, intended to enhance the nature and quality of the educational experience, has also been significant, for example using 1990 prices, expenditure per pupil was 30 times higher by the late 20 th century compared to the mid-nineteenth century.

Within this overall trend of rising public expenditure associated with the expansion of educational provision, there have been changes in expenditure which can be associated with long-term economic fluctuations, which have been considered to correspond with Kondratiev cycles or long waves (see also Loucã \& Reinjders, 1999), as evident in the UK (Carpentier, 2001b). Prior to 1945, expenditure on education tended to increase at times of economic downturns and fall during periods of economic prosperity. After 1945, the linkage between educational expenditure and economic trends was reversed. The move to procyclical public expenditure on education may be linked to recognition that education could be a driver in the economic system, as suggested by human capital theory. Educational expenditure grew significantly in the immediate post-World War II period, associated with relative economic improvement and with educational expansion, for example the introduction of free secondary education for all in the 1944 Education Act in England and Wales. The period of continuing educational expansion and increased public expenditure was however challenged by the economic crisis of 1973. The period since has been associated with policy concerns to curb public expenditure. Education funding in the UK has therefore been affected by both the aftermath of the 1973 economic crisis, resulting in reductions in overall expenditure levels as discussed above, and a perceived political "crisis» in the legitimacy and purpose of the education system related to the 1976 «Great Debate» which questioned whether education was, in fact, delivering economic returns (see Chitty, 1989). The resulting policy shifts, which found particular force in the 1988 Education Reform Act in England and Wales, involved substantial changes in the curriculum, management, structure and financing of education (Whitty et al., 1998). Such shifts in economic and education policy have been associated with an increased emphasis on ensuring efficiency, in terms of maximising outputs, such as educational attainment, from inputs, including finance (see Campbell \& Whitty, 2000), although such input- 
output conceptualisations underplay the importance of processes within educational provision and resource usage.

The overall trends in public expenditure for education described here are not unique to the UK, as similar patterns are evident in France and Germany for example (see Carpentier, 2001b; Carry, 2000; Diebolt 1995; Fontvieille 1990; Michel, 1999). Shifting patterns and reductions in public expenditure are evident also in developing countries (Bourdon, 2002; Bouslimani, 2002; Eicher, 2000; Lange, 2001). Mingat and Tan (1998) outline differences in public investment for education and economic growth between «rich» and "poor» countries and within these countries reflecting different policy choices. For example, the increasing share of expenditure on secondary school education linked to its expansion in "rich» countries, and shifts in the level of private sources of funding for post-compulsory education, for example associated with student fees.

Nevertheless, as Patrinos (2000) has indicated from international comparisons, the issue of expenditure and educational outcomes is not as straightforward as increased resources resulting in increased educational attainment scores (see also Beaton et al., 1996a, 1996b; Mingat \& Tan, 1998; OECD, 1998). For example, Mingat and Tan (1998) demonstrate that economically richer countries tend to have extended the level of educational provision, but improvements in international test scores are not as significant - with gradual improvements reflecting policy choices and educational processes rather than expenditure levels. Although education expenditure may result in improving the quantity of education available, for example through increased access and provision of places, this does not necessarily contribute to improvements in the quality of such provision, for example in terms of educational processes and outcomes.

The issue, therefore, is not simply about levels of resources. Hanushek's $(1986,1989,1996,1997)$ reviews of US research evidence mapping resource inputs to student achievements have concluded that «There is no strong systematic relationship between school expenditures and student performance» (Hanushek, 1986 , p. 1162), although there have been questions about the reliability of the analyses (see Hedges et al., 1994). Similarly an international review of the relationship between resource allocation and pupil attainment concluded that there was a lack of conclusive evidence that «more resources are required to achieve higher educational outcomes» (Vignoles et al., 2000). However, behind these overarching statements, there is evidence about the need for sufficient resources to ensure adequate provision (see Mortimore, 1988; Sammons et al., 1995) and that there are specific aspects of provision where additional resources can bring direct or indirect benefits for associated educational outcomes. The processes which involve transforming «inputs» to desired educational «outputs» must involve consideration of learning, teaching and classroom processes, for example as evident in school effectiveness and school improvement research findings (see Sammons, 1999; Teddlie \& Reynolds, 2000). Policy makers therefore need to take account of the fact that while resources may not determine effectiveness 
they can contribute to an improved educational experience (see Mortimore et al., 1988).

Policy decisions must balance issues of educational effectiveness and economic effectiveness and, to date, such issues remain open to considerable debate (see OECD, 2002, for example). The experience of educational expansion has raised funding dilemmas not only in terms of the overall level and distribution of resources, but also in seeking to ensure that the mechanisms of funding are appropriate. Evidence relating to options for funding mechanisms, and the impact of specific mechanisms in practice, as discussed below, are therefore significant to policy debates concerning how to maintain educational improvement, while seeking also to curb increases in public expenditure.

\section{Funding Mechanisms and Educational Improvement}

In this section, we examine current policy debates and developments in relation to funding mechanisms for education in practice. Following the differentiation between funding needs and modalities for post-compulsory education and compulsory education identified by some economists (see Barr, 2000; Eicher, 2000), we look in turn at each of these sectors of provision. In both these sectors, the constraints on public expenditure triggered by the 1973 economic crisis, alongside policy concerns for educational expansion have resulted in changes to funding mechanisms as part of wider reforms of compulsory and post-compulsory provision. Our purpose is to evaluate the evidence relating to particular forms of funding which have been applied and/or are being promoted. We are concerned also to explore the implications for educational improvement as far as possible. However, in doing so, it is important to recognise that there are different ways of approaching the issues of improvement, for example in terms of the quantity of educational provision (associated with expansion and access) and the quality of such provision (in terms of educational processes and outcomes). There is a need also to consider improvements in terms of the efficiency of education systems in meeting such criteria and the equity implications for individuals and institutions. Although our focus is mainly on England, UK, where there has been significant developments in policy responses to funding concerns for education in recent years, we draw also on wider policy debates and experiences where appropriate to further our analysis.

\section{Compulsory Education}

The importance of compulsory education in ensuring individuals have a right to participate in education and gain a grounding in the "basics» (reading, writing, mathematics for example) has resulted in proposals that governments should direct expenditure in particular to this sector of provision (see Wolf, 2002; World Bank, 1995). In an overview of developments, Patrinos (2000) points to a shift- 
ing balance between supply-driven expansion of expenditure for compulsory education and the introduction of demand-side mechanisms associated with market forces and choice which can be witnessed internationally, and particularly in the US and UK. Demand-side financing involves mechanisms "whereby public funds are channelled directly to individuals or to institutions according to expressed demand» (Patrinos, 2000, p. 62). Such mechanisms can include a range of forms of voucher mechanisms, fees, loans, scholarships and stipends (see Patrinos \& Ariasingam, 1997).

The funding of public compulsory education has been significantly reformed in the UK since the late 1980s (see for example Campbell, 1999). Experiments with vouchers for nursery education were however short-lived. The Assisted Places Scheme, which sought to directly fund individuals from low income families to receive private school education, introduced by the Conservative government was also abolished by the New Labour government, elected in 1997. Evidence indicated that the Assisted Place Scheme was not, in practice, benefiting those from the lowest income groups or from minority ethnic groups (see Edwards et al., 1989), and therefore was not serving to redistribute educational opportunities as initially envisaged. The introduction of forms of school-based devolved financial management (through Local Management of Schools and Grant-Maintained Status from the late 1980s and their replacement by Fair Funding from the late 1990s onwards in England) has however become central to UK funding mechanisms and education policy (see Campbell, 1999; Campbell \& Whitty, 2000). The particular form of devolved financial management applied, including financial delegation to schools based on predominantly per capita formula, combined with parental choice policies to stimulate competition between schools and the publication of school performance indicators to inform such choice has resulted, in effect, to what Thomas and Bullock (1994, p. 41) defined as the "pupil-as-voucher system». In the UK therefore, as evident also in New Zealand, parts of Australia and some states in the US for example (see Whitty et al., 1998), the modalities of education finance have been significantly reformed during the past two decades with an increasing emphasis on the development of a "quasi-market» in education (LeGrand \& Bartlett, 1993). Levacic (1995, p.167) defines this «quasi-market» as involving «a separation of purchaser from provider and an element of user choice between providers». Nevertheless, a framework of regulation, oversight and as necessary direct central government intervention remains and can indeed be strengthened.

A key policy argument for the introduction of devolved funding in education systems is that it will increase managerial and economic efficiency, which in turn will have positive benefits for educational efficiency, in terms of outcomes achieved for resources inputted. In practice in the UK, over time headteachers have broadly welcomed the capacity for local decision making and the ability to purchase a range of resources to meet their school and pupils' needs (Adler et al., 1996; Bullock \& Thomas, 1997; Campbell, 2001; Levacic, 1995). However, 
classroom teachers who have been surveyed tend to be less positive about the impact of devolved financial management for teaching and learning specifically (Bullock \& Thomas, 1997). Initially there were concerns that the «start up» costs associated with creating devolved management structures may actually have reduced the level of resources directly available for educational use (Campbell \& Whitty, 2000). There is evidence that devolved funding can involve a flow of resources into managerial and administrative processes, rather than classroom activities (see Whitty et al., 1998). Furthermore, while headteachers are generally positive about the capacity to direct funding when it enables the purchase of new resources and staffing, they are less positive when it involves having to manage budget reductions (see Ball, 1993). Nevertheless, some evidence suggests that devolved financial management procedures offer the possibility to improve managerial efficiency of enabling some financial decisions to be targeted to local needs (Campbell, 2001; Levacic, 1995). Levacic's (1995) study indicated that devolved funding may be linked with cost efficiency.

There remains considerable debate as to whether the linkage of financial devolution to quasi-market reforms has generated improvements in educational outcomes and efficiency at the systemic level. Some research in England, evaluating the impact at a national level for all secondary schools has suggested that improved efficiencies in terms of educational outcomes have occurred at the same time as the implementation of devolved funding and parental choice policies (Bradley et al., 1998; Gorard \& Fitz, 2000). Bradley et al.'s (1998) research sought to evaluate improvements in school efficiency by measuring the relationship and changes between school-level inputs, examination results and attendance figures. Their findings suggest increases in relative and absolute efficiency at the national level in England between 1993 and 1997, which they consider to be associated with increased competition between schools. These research findings indicate also that such efficiency gains coincided with decreasing social segregation between schools at a national level (see Bradley et al., 1998; Gorard \& Fitz, 2000; see also Adnett \& Davies, 2002).

However, Noden's (2000) analysis, using a different methodology, pointed to increasing social segregation between English secondary schools during 1994 to 1999. Even in Bradley et al.'s (1998) research different impacts between different types of school were apparent, with selective, independent and single sex schools being identified as more efficient. These are also schools whose admissions criteria tend to favour a higher proportion of the school population having higher ability levels. Levacic and Woods' (1999) study revealed that, even if nationally overall improvements were occurring, this masked considerable local variation and increasing social polarisation between schools affecting 30 to 40 per cent of localities in England. Local school hierarchies are becoming pronounced where schools are ranked by parents and others according to «desirable features», particularly academic results and social position (Levacic \& Woods, 1999; Woods \& Levacic, 2002). These schools become the schools of choice for 
«alert» and aspirant parents operating choice (see Gewirtz et al., 1995). Similarly, schools that are in demand have more scope to be selective, whether formally or otherwise, and tend to favour academic students who have considerable funding value by staying in education longer and producing higher attainment results which bolster the school's performance (see Bartlett \& Le Grand, 1993; Gewirtz et al. 1995). Contrary to the claims of advocates of quasi-markets, the combination of devolved funding and parental choice appears to benefit both schools and parents that are already in financially, socially and educationally advantaged positions (see Gewirtz et al., 1995; Gibson \& Asthana, 1999; Levacic \& Hardman, 1999).

International evidence, particularly from New Zealand and the US, is similarly controversial but tends to re-enforce concerns about the equity issues associated with quasi-markets and the lack of substantial evidence directly linking devolved funding and educational improvement (see for example Whitty, 2002; Wylie, 1994, 1995, 1997). Such equity and educational considerations must be taken into account in current debates about the applicability and effects of forms of demand-side financing mechanisms for «developing» countries (Patrinos and Ariasingam, 1997).

The concern that devolved funding to schools, coupled with quasi-market reforms of parental choice and per capita funding, has not to date conclusively raised educational standards for all could lead to different policy conclusions. Supporters of market forces in education argue that this is as yet «unfinished business" (Douglas, 1993), as the "quasi» element of the reforms has inhibited the free operation of the market (see also Chubb \& Moe, 1990, and Tooley, $1995,1996,2000)$. An opposing argument is that the market based elements of the financial reforms should be replaced by a national funding formula for schools which targets additional funding to schools with high intakes of socially disadvantaged and potentially under-achieving students, serving a redistributive function (see Sammons et al., 1997). The prospect for enhanced local, regional funding has also been promoted (Howson Commission, 2002) to target local needs and imperatives, however there may be limitations on the level of investment and redistribution potential through local taxation as the main funding source. Another approach is the need to develop more sophisticated funding formulae which link resource decisions to knowledge of per pupil costs per learning outcomes. If such funding mechanisms replaced the current predominantly per capita funding approach with one where formula funding were based on educational and social need and removed the linkage with the quasi-market elements of reform, this may help to overcome some of the inequities of the existing funding system. One funding mechanism that has been advocated, and applied in some settings, is the development of «activity-led funding» which links resource allocation to agreed educational objectives, as determined by policy decisions (see Abu-Duhou et al., 1999; Ross and Levacic, 1999).

There remains however considerable work to fully identify the costs of spe- 
cific educational activities and their linkages to educational objectives and outcomes. As Thomas and Martin (1996, p. 23) concede, "we do not know [...] precisely how pupils learn and the appropriate mix of resources to support that learning». Nevertheless, studies which reveal that similar schools, with similar levels of funding, can be differentially effective in terms of educational outcomes achieved, indicate the need to consider the processes within these schools (see Vignoles et al., 2000). Analysis of resources which can contribute to improved educational processes and outcomes has pointed to the potential importance of investments within schools for teachers and classroom sizes in particular.

Research has suggested that teacher education and preparation can contribute to improved student attainments (see for example, Lord 1984; Monk, 1994). The impact of teacher experience, particularly at the early stages of a teacher's career, has been identified as contributing to student attainments (see Hanushek et al., 1998; Krueger, 1999), whereas teacher inexperience can have a negative impact on student attainment results (see Lord, 1984). There is some evidence that higher teacher salaries are associated with higher student achievements (see Dewey et al., 2000) and that the impact is particularly important for tenured, experienced teachers (Hanushek et al., 1999). The number and use of part-time teaching staff has also been found to have a positive impact on exam performance (Bradley \& Taylor, 1998). Vignoles et al. (2000) suggest that this may be because of added expertise in specific subject areas and potential staffing flexibility. Such findings relating to expenditure on teachers are important to policy developments concerning teacher education, recruitment, retention and payment, and the involvement of other staff within classrooms.

In England, a raft of policies relating to requirements for initial teacher education and standards for practice once in post to increase experience have been applied (see DfES, 2001; TTA, 2002 for example). While teachers' relative salaries have declined during the 1990s in England (as evident in other countries also, see Mingat \& Tan, 1998), bonuses for new entrants in subjects where there are recruitment shortages and the introduction of performance related pay have been used as mechanisms to encourage retention and improved teacher outputs in specified areas of performance (see Dolton et al., 2003). An increasing range and number of assistant and support staff working in classrooms with teachers is central to Government policies concerned with «School Workforce Remodelling». The full impact of these policy reforms, and whether they contribute to improved student outcomes as anticipated by the Government, requires further evaluation (see Dolton et al., 2003).

Research has analysed also the potential contribution of investment in classroom sizes. Overall, the findings relating to class sizes and student attainment have been mixed with some research pointing to a positive relationship between smaller class sizes and increased student attainment (Angrist and Lavy, 1999; Hanushek et al., 1998; Krueger, 1999), while other studies have found negative (or insignificant) results (Cooper \& Cohn, 1997; Goldhaber \& Brewer, 1999; 
Goldhaber et al., 1999; Hoxby, 1998). Some early studies pointed to benefits for students' attainments associated with larger class sizes (see Davie et al., 1972; Little et al., 1973; Morris, 1959; Wiseman, 1967). From an economic perspective, cost benefit analysis has been adopted to investigate whether on balance the resource implications of reducing class sizes are worthwhile for the associated outcomes (Vignoles et al., 2000). In countries where universal compulsory education has not yet been fully established, analysis has suggested the need to focus on continuing to expand provision rather than reducing existing class sizes (see Mingat and Tan, 1998). However, against these mixed overall findings, there is evidence that, where compulsory education is embedded, smaller class sizes may be beneficial for young children and particularly for children in disadvantaged contexts, for example low socio-economic status and potentially low achieving children (see Blatchford et al., 2002; Hanushek et al., 1998; Mortimore et al., 1988; Vignoles et al., 2000). Research has indicated also that the forms of interactions, groupings, teaching and learning within classes of different sizes are significant (Blatchford et al., 2001; Wright et al., 1997). Larger classes with a range of groupings may undermine teacher-student interaction, whereas smaller classes can enable whole class groupings with a high level of interaction (Blatchford et al., 2001). An early policy initiative of the UK New Labour government was to introduce targets to reduce class sizes during the early years of compulsory education.

In addition to evidence concerning resource decisions within schools, research has also pointed to the potential benefits of using targeted funding from central government to schools to support specific policy initiatives for expected educational outcomes. In particular, targeted funding to support early intervention pre-school, literacy and numeracy, resourcing for designated «special educational needs» and additional resourcing for other forms of educational need, particularly in areas of social disadvantage, can be significant (see Mortimore \& Whitty, 1997; Vignoles et al., 2000). The outcomes of Sammons et al.'s (1997, pp. 188-189) research examining school effectiveness included the policy recommendation that: "It is vital that such resources are specifically targeted at students most in need». Recently, while retaining (and extending) quasi-market policies linked to demand-side funding mechanisms, the UK New Labour government have introduced targeted funding and policy initiatives designed to tackle educational under-achievement, particularly in areas of socio-economic deprivation. Whether such a combination of financial methods and educational policies can serve to raise attainment for all pupils without a more fundamental reform and redistribution of resources remains to be seen, but it does indicate at some level a recognition that quasi-market funding mechanisms have not benefited all equally and indeed can further disadvantage vulnerable groups.

\section{Post-Compulsory}

In developed countries, economists have become increasingly interested in fund- 
ing modalities for higher education and the dilemmas posed by expanding access and securing adequate funding, particularly in periods of constraints on public expenditure (see Carpentier, 2001a). Eicher (2000) identifies a clear trend towards higher fees in post-compulsory education (university level) - although the manner in which these fees are paid varies considerably. A review of the financing and management of higher education conducted for the World Bank (Johnstone with Arora \& Experton, 1998) pointed to three key developments in what they identified as a "worldwide reform agenda» (p. 1):

1. Supplementation of public or governmental revenues with non-governmental revenues.

2. Reform of public sector financing.

3. Radical change (restructuring) of the universities and other institutions of higher education.

Policy debates concerning higher education funding have involved consideration of whether investment in education should be directed by the state, devolved to restructured institutions or the responsibility of individuals; and whether any public funding provided for individuals should take the form of a grant, loan or subsidy and with what equity implications. Barr (2003) has argued that any reform of higher education must combine a concern with economic growth and social objectives. To support economic growth, higher education must be of a highly quality, responsive to economic shifts and support knowledge development. To support social inclusion, wide access to higher education needs to be established. For governments, the aspiration for expanded access has resulted in funding dilemmas and a shifting balance between public and private funding to support the quantity of places required (Barr, 1993). Concerns about funding higher education relate also to quality concerns, for example if expanded access results in declining resources per student (in England expenditure per students declined by over 40 per cent between 1980 and 1997; see Barr, 2003).

The possibility of removing government direct involvement in higher education has been suggested by proponents of market forces (see Hare, 2000), but this takes little account of the externalities associated with higher education, potential market failures and equity considerations (see Coates \& Adnett, 2003). Although not as well developed as for compulsory education, however, forms of quasi-market competition between higher education institutions have been encouraged in the UK. In practice, such competition, as evident for compulsory education (see above), may tend to favour institutions which attract students with higher academic attainments resulting in hierarchies of provision and social stratification (Coates \& Adnett, 2003). This raises equity concerns about the distribution of students within and between higher education institutions, alongside concerns about overall participation rates.

In the UK, the structure and funding of higher education has been reformed 
during the post-War period, with particular expansion in the 1960s, restructuring in the 1990s and current debates concerning access and funding. The target of 50\% of all 18-30 year olds in England participating in higher education by 2010 has been set (DfES, 2003). This is particularly significant for the majority of individuals with low socio-economic status who currently do not participate in higher education (see Connor et al., 2001). For example, "young people from professional backgrounds are over five times more likely to enter higher education than those from unskilled backgrounds» (DfES, 2003, 1.28). The government in England are therefore promoting a package of reforms designed to enhance access to higher education, including collaboration with schools, colleges and employers, increasing information to attract students who may not have considered further study and developing shorter, vocationally orientated «foundation degrees' (see DfES, 2003; HEFCE, 2003). Alongside attitudinal and cultural barriers to entering higher education (see Ball et al., 2002; Hutchings and Ross, 2003; Reay et al., 2001), financial factors are also very important. Potential students who select not to enter higher education frequently cite concerns about the debt that will be incurred and loss of income during participation in higher education (see Callender, 2003; Connor $e t$ al., 2001). Research has indicated also that the recruitment, retention and progression of students who would not have traditionally participated in higher education involves resource implications for higher education (PA Consulting Group, 2002). Therefore, policy questions relating to access and participation in higher education require attention to funding concerns for institutions, individuals and for governments.

In the UK, three main options for funding mechanisms have influenced policy debates: tax funding with no direct fees to students; tax funding plus upfront charges (as implemented since 1998); or tax funding plus deferred charges (the currently proposed system in England; see DfES, 2003). Advocates of tax funding without charges being paid directly by the individual student argue that such an approach is more equitable as education remains "free at the point of use». However, Barr (2003) argues that, in practice, such systems have not been more equitable, citing the evidence that those from the lowest income groups have also been those who are most unlikely to enter higher education. Barr (2003) suggests that such funding regimes result in a shortfall in funding for higher education, which undermines the ability to target resources to enhance access and to support a quality educational provision. Equity arguments are also invoked about the claim that, given the evidence of substantial economic and social benefits accrued by graduates why should non-graduates subsidise such provision through taxation. Demographic trends point also to a likelihood of rising numbers of students in higher education within the next decade and a significant funding deficit without reform of higher education finance. Barr (2003), however, rejects also the system of tax funding plus upfront fees implemented in England since 1998 on grounds of equity and efficiency - as there is little choice for students in the manner of payment and the level of upfront payment may 
discriminate against those from lower-income households. According to Barr (2003), therefore, tax funding plus deferred charges are the most likely to combine needed investment with scope for equity and access concerns. In such a system, education can remain "free at the point of use» and future payments, linked to salary levels, can take account of income differentials and capacity to pay. To ensure enhanced access, however, such systems must also provide targeted support and resources to encourage those from lower-income households to participate in higher education. Loans of a sufficient level to cover living costs and expenses are required, with additional direct financial support available for individuals with low socio-economic status, and any future repayments must take a realistic account of level of income required before contributions can be made. Whether, in practice, a system of higher education funding can be implemented which will facilitate a quantitative increase in provision and a qualitative improvement, and combine efficiency and equity concerns, requires further research.

\section{Conclusions}

Analysing the policy implications associated with funding mechanisms for educational improvement is problematic. A significant factor is the difficulty of disentangling financial processes and inputs affecting education from the broad range of educational change that is taking place, involving changes in access to educational institutions, teaching and learning processes within education and expected outcomes from education. Furthermore, the range of proposed outcomes from education, for example widening participation, raising attainment overall, tackling under-achievement and providing a skilled workforce, can place considerable, and often conflicting, demands on the most appropriate allocation and distribution of funding. Related policy questions about linking education finance to anticipated specific educational outcomes can be approached as a technical question requiring increasing sophistication in understanding resource costs, financial mechanisms and their linkage to specified educational outputs. However, it is apparent that in analysing the best policy approaches and solutions, such questions are not entirely technical. Rather these questions raise fundamental questions about the purpose and value of education and for politicians about economic impact and the ideological and electoral appeal of different approaches and related outcomes.

We have argued that investment in education matters for individuals, economies, societies and governments, and therefore the funding of education is a key concern for economic policy and education policy. This involves the need for policy makers to evaluate funding mechanisms and their implications, including the balance between public and private investments and returns, and the distribution of funding between different sectors, particularly for countries at 
different stages of economic and educational development, together with their impacts on individuals' educational participation and outcomes. The human right to access basic compulsory education is a priority where this has not yet been achieved. In further promoting educational improvement, enhanced educational access, participation and outcomes are key policy considerations. Therefore, although different funding mechanisms can be applied for different sectors of education (for example, compulsory and post-compulsory), attention is also required supporting learners' transitions and achievements throughout the formal education system. Despite overall improvements in education standards, significant variations for groups of students, for example by socio-economic status, gender and ethnicity, remain unacceptable in the UK and internationally ${ }^{3}$. Governments need also to take account of supporting transitions for individuals beyond their formal education, particularly for those in socially disadvantaged contexts, to ensure future economic activity, lifelong learning and social benefits. Furthermore, while the benefits from investment and participation in education are significant, governments cannot focus on educational improvement alone as the proposed mechanism for future economic growth and social change. Rather policy concerns about public expenditure and education finance must also consider wider social and economic policy issues, particularly the need to tackle poverty at source in order to support social and economic improvement.

\section{Notes}

1 Grao and Mora (2000: p. 3) outline the following key topics for Economics of Education:

* Human capital (changes in productivity).

* Economic efficiency (how to allocate resources).

* Contribution of education to economic development.

* Internal effectiveness of education (relationships between inputs and outputs in the educational process).

* Demand for educated manpower.

* Financing of education.

* Equity and effectiveness.

2 See Carpentier 2001 and 2003 for further details of methodology. Public educational expenditure in these calculations include pre-school, compulsory and post-compulsory education and related expenditure, for example for administration and school welfare.

3 See for example data and analysis from the OECD Progamme for International Student Assessment (PISA) available at: www.pisa.oecd.org, and for England the Office for Standards in Education (Ofsted) available at: www.ofsted.gov.uk 


\section{References}

Abu-Dubou, I., Downes, P. \& Levacic, R. (1999). Component 1: Basic Student Allocation. In K.N. Ross \& R. Levacic (Eds.), Needs-Based Resource Allocation in Education, 59-90. Paris: UNESCO Publishing.

Adler, M., Arnott, M., Bailey, L., McAvoy, L., Munn, P. \& Raab, C. (1996). Devolved School Management in Secondary Schools in Scotland: A Report to the Scottish Office Education and Industry Department. Edinburgh: University of Edinburgh.

Adnett, N. \& Davies, P. (2002). Market Forces for Schooling: An Economic Analysis. London: Routledge.

Angrist, J. \& Lavy, V. (1999). Using Maidmondies Rule to Estimate the Effect of Class Size on Scholastic Achievement. Quarterly Journal of Economics, 114, (2), 533-575.

Archer, L., Hutchins, M., Ross, A., Leathwood, C., Gilchrist, R. \& Phillips, D. (2003). Higher Education and Social Class: Issues of Exclusion and Inclusion. London: Routledge Falmer.

Ball, S.J. (1993). Culture, Cost and Control: Self-Management and Entrepreneurial Schooling in England and Wales. In J. Smyth (Ed.), A Socially Critical View of the Self-Managing School, 63-82. London: The Falmer Press.

Ball, S.J., Davies, J., David, M. \& Reay, D. (2002a). ,Classification' and ,Judgement': Social Class and the Cognitive Structures of Choice of Higher Education. British Journal of Sociology of Education, 23, (1), 51-72.

Ball, S.J., Ready, D. \& David, M. (2002b). Ethnic Choosing: Minority Ethnic Students and Higher Education Choices. Race, Ethnicity and Education, 5, (4), 333-357.

Barr, N. (1992). Economic Theory and the Welfare State: A Survey and Interpretation. Journal of Economic Literature, 30, (2), 741-803.

Barr, N. (1993). Alternative Funding Resources for Higher Education. Economic Journal, 103, 718-728.

Barr, N. (2003). Financing Higher Education: Comparing the Options. London School of Economics Working Paper, June.

Bartlett, W. \& LeGrand, J. (1993) (Eds.). Quasi-Markets and Social Policy. London: Macmillan.

Becker, G.S. (1962). Investment in Human Capital: A Theoretical Analysis. The Journal of Political Economy, 70, (5), 9-49.

Blatchford, P., Baines, E., Kutnick, P. \& Martin, C. (2001). Classroom Contexts: Connections Between Class Size and Within Class Groupings. British Journal of Educational Psychology, 71, 283-302.

Blatchford, P., Goldstein, H., Martin, C. \& Browne, W. (2002). A Study of Class Size Effects in English School Reception Year Classes. British Educational Research Journal, 28, 169185.

Bourdon, J. (2002). La Banque Mondiale et l'éducation, ou: est-il plus simple de construire de grands barrages que de petites écoles? Economies et Sociétés, Série F, 40, DéveloppementIV, 501-532.

Bouslimani, A. (2002). La régulation systémique à l'épreuve de la problématique éducationdéveloppement: vers l'élaboration de la notion de système social d'accumulation. Economies et Sociétés, Série F, 40, Développement-IV, 475-500.

Bradley, S., Johnes, G. \& Millington, J. (1998). School Choice, Competition and the Efficiency of Secondary Schools in England. University of London: Centre for Research in the Economics of Education.

Bullock, A. \& Thomas, H. (1997). Schools at the Centre? London: Routledge.

Callender, C. (2003). Attitudes to Debt and its Impact on Participation in Higher Education. www.universitiesuk.ac.uk

Campbell, C. (1999) Les Modalités de financement de l'enseignement en Angleterre. Revue Internationale d'Éducation Sèvres, 22, 61-80. 
Campbell, C. (2001). School-Based Management: An Evaluation of Policy and Practice in Scotland. International Studies in Educational Administration, 29, (1), 2-18.

Campbell, C. (2002) (Ed.). Developing Inclusive Schooling: Perspectives, policies and practices. London: Institute of Education, University of London.

Campbell, C. \& Whitty, G. (2000). Devolved Funding for Schools: The Experiences of England and Scotland. In P. Karmel (Ed.), School Resourcing: Models and Practices in Changing Times, 55-66. Deakin: The Australian College of Education.

Carpentier, V. (2001a). Système éducatif et performances économiques au Royaume-Uni: 19ème et 20ème siècles. Paris: L'Harmattan.

Carpentier, V. (2001b). Effort public d'éducation et croissance économique de long terme au Royaume-Uni. Economies et Sociétés, Série AF, Histoire économique quantitative, 28,11951221.

Carpentier, V. (2003). Public Expenditure on Education and Economic Growth in the UK, 1833-2000. History of Education, 32, (1), 1-15.

Carry, A. (1999). Le compte satellite rétrospectif de l'éducation en France:1820-1996. Economies et Sociétés, Série AF, Histoire quantitative de l'économie française, 25, 1-273.

Coates, G. \& Adnett, N. (2003). Encouraging Cream-Skimming and Dreg-Siphoning? Increasing Competition Between English HEIs. British Journal of Educational Studies, 51, (3), 202-218.

Cohn, E. \& Addison, J.T. (1998). The Economic Returns to Lifelong Learning. Education Economics, 6, 253-308.

Conlon, G. \& Chevalier, A. (2002). Financial Returns to Undergraduates: A Summary of Recent Evidence . London: The Council for Industry and Higher Education.

Connor, H., Dewson, S., Tyers, C., Eccles, J., Regan, J. \& Aston, J. (2001). Social Class and Higher Education: Issues Affecting Decisions on Participation by Lower Social Class Groupings. London: Department for Education and Employment.

Cooper, S.T. \& Cohn, E. (1997). Estimation of a Frontier Production Function for the South Carolina Educational Process. Economics of Education Review, 16, (3), 313-327.

Davie, R., Butler, N. \& Goldstein, H. (1972). From Birth to Seven. London: Sage.

Denison, E.F. (1967). Why Growth Rates Differ: Post-war Experience in Nine Western Countries. Washington D.C.: The Brooking Institution.

Department for Education and Skills (2001). Teachers' Standards Framework. London: Department for Education and Skills.

Department for Education and Skills (2003). The Future of Higher Education. White Paper, January. London: Department for Education and Skills.

Dewey, J., Husted, T.A. \& Kenny, L.W. (2000). The Effectiveness of School Inputs: A Product of Misspecification? Economics of Education Review, 19, (1), 27-45.

Diebolt, C. (1995). Education et croissance économique. Le cas de l'Allemagne au XIXème et XXème siècles. Paris: L'Harmattan.

Dolton, P., McIntosh, S. \& Chevalier, A. (2003). Teacher Pay and Performance. London: Institute of Education, University of London.

Douglas, R. (1993). Unfinished Business. Auckland: Random House.

Edwards, T., Fitz, J. \& Whitty, G. (1989). The State and Private Education: an Evaluation of the Assisted Places Scheme. London: Falmer Press.

Eicher J.C. (2000). The Financing of Education: An Economic Issue. European Journal of Education, 35, (1), 33-44.

Fontvieille, L. (1990). La croissance de la dépense publique d'éducation. Formation-emploi, 31, (juillet-septembre), 61-71.

Fontvieille, L. \& Michel, S. (2001). La dimension humaine dans les théories du développement: poussées objectives et reculs dans les années de crise. Economies et Sociétés, Série F, $38,311-342$. 
Gewirtz, S., Ball, S.J. \& Bowe, R. (1995). Markets, Choice and Equity . Buckingham: Open University Press.

Gibson, A. \& Asthana, S. (1999). Schools, Markets and Equity: Access to Secondary Education in England and Wales. Paper presented at the American Educational Research Association, Annual Meeting, Montreal, 21 April.

Goldhaber, D.D. \& Brewer, J. (1999). Why don't Schools and Teachers Seem to Matter? Assessing the Impact of Unobservables on Education Production. Journal of Human Resources, 32, (3), 505-523.

Goldhaber, D.D., Brewer, D.J. \& Anderson, D.J. (1999). Three Way Error Components Analysis of Educational Productivity. Education Economics, 7, (3), 199-208.

Gorard, S. \& Fitz. J. (2000). Investigating the Determinants of Segregation Between Schools. Research Papers in Education, 15, (2), 115-132.

Grao, J. \& Mora, J. (2000). Editorial. European Journal of Education, 35, (1), 1-5.

Hanushek, E.A. (1986). The Economics of Schooling: Production and Efficiency in Public Schools. Journal of Economic Literature, 24, (3), 1141-1177.

Hanushek, E.A. (1989). The Effect of Differential Expenditures on School Performance. Educational Researcher, 18, (4), 45-51.

Hanushek, E.A. (1996). The Identification of School Resource Effects. Education Economics, 4, (2), 105-125.

Hanushek, E.A. (1997). Effects of School Resources on Economic Performance. Education Evaluation and Policy Analysis, 19, (2), 141-164.

Hanushek, E.A., Kain, J.F. \& Rivkin, S.G. (1998). Teacher, Schools, and Academic Achievement. National Bureau of Economic Research Working Paper 6691.

Hanushek, E.A., Kain, J.F. \& Rivkin, S.G. (1999). Do Higher Salaries Buy Better Teachers? National Bureau of Economic Research Working Paper 7082.

Hare, P. (2000). Constraints and Incentives in the UK University System . Heriott-Watt University, School of Management, Economics Division, Discussion Paper No. 2000/3.

Hartog, J. (2000). Human Capital as an Instrument of analysis for the Economics of Education. European Journal of Education, 35, (1), 7-20.

Heald, D. (1983). Public Expenditure. Oxford: Basil Blackwell.

Hedges, L.V., Laine, R.D. \& Greenwald, R. (1994). Does Money Matter? A Meta-Analysis of Studies of the effects of Differential Inputs on Student Outcomes. Educational Researcher, 23, (April), 5-14.

Higher Education Funding Council for England [HEFCE] (2001). The Wider Benefits of Higher Education. Bristol: HEFCE.

Higher Education Funding Council for England [HEFCE] (2003). Realising a Vision for Higher Education: Annual review 2002-03. London: Higher Education Funding Council for England.

Howson Commission (2002). No Child Left Behind: Report of the Howson Commission into School Education. UK Liberal Democrat Party.

Hoxby, C.M. (1998). The Effects of Class Size and Composition on student achievement: New Evidence from Natural Population Variation. National Bureau of Economic Research 6869.

Johnstone, D. B. with Arora, A. \& Experton, W. (1998). The Financing and Management of Higher Education: A status report on worldwide reforms. Washington, D.C.: The World Bank.

Krueger, A.B. (1999). Experimental Estimates of Education Production Functions. Quarterly Journal of Economics, 114 , (2), 497-532.

Lange, M.F. (2001). Des écoles pour le Sud. La Tour d'Aigues: Editions de L'Aube [IRD, n¹7].

Levacic, R. (1995). Local Management of Schools: Analysis and Practice. Buckingham: Open University Press.

Levacic, R. \& Hardman, J. (1999). Competing for Resources: the Impact of Social Disadvantage and Other Factors on English Secondary Schools' Financial Performance. Oxford Review of Education, 24, (3), 308-328. 
Levacic, R. \& Woods, P. (1999). Polarisation and Inequalities Between Secondary Schools in England: Effects on School Practice and Performance. Paper presented at British Educational Research Association, University of Sussex.

Little, A., Mabey, C. \& Russell, J. (1973). Class Size, Pupil Characteristics and Reading Attainment. In V.Southgate (Ed.), Literacy at All Levels; Proceedings of the 8th Annual Study Conference, 205-213. London Ward Lock.

López, R., Thomas, V. \& Wang, Y. (1998). Addressing the Education Puzzle: The Distribution of Education and Economic Reform. Washington, D.C.: World Bank.

Lord, R. (1984). Value for Money in Education. London: Public Money.

Loucà, F. \& Reijnders, J. (Eds.) (1999). The Foundations of Long Wave Theory. Cheltenham: Edward Elgar Publishing.

Lucas, R.E. (1988). On the Mechanics of Economic Development. Journal of Monetary Economics, 22, 3-42.

Michel, S. (1999). Education et croissance économique en longue période. Paris: L'Harmattan.

Mincer, J. (1958). Investment in Human Capital and Personal Income Distribution. The Journal of Political Economy, 66, (4), 281-302.

Mingat, A. \& Tan, J. (1996). The Full Social Returns to Education: Estimates based on countries' economic growth and performance. Washington, D.C.: World Bank.

Mingat, A. \& Tan, J. (1998). The Mechanics of Education: Progress from Cross-Country Data. Washington, D.C.: World Bank.

Monk, D.H. (1994). Subject Area Preparation of Secondary Mathematics and Science Teachers and Student Achievement. Economics of Education Review, 13, (2), 125-45.

Morris, J. (1959). Reading in a Primary School. London: Newness.

Mortimore, P., Sammons, P., Stoll, L., Lewis, D. \& Ecob, R. (1988). School Matters: The Junior Years. Wells: Open Books.

Mortimore, P. \& Whitty, G. (1997). Can School Improvement Overcome the Effects of Disadvantage? London: Institute of Education, University of London.

Noden, P. (2000). Rediscovering the Impact of Marketisation: Dimensions of Social Segregation in England's Secondary Schools, 1944-99. British Journal of Sociology of Education, 371-90.

Organisation for Economic Co-operation and Development [OECD] (2002). Education at a Glance. Paris: OECD.

OECD \& UNESCO (2003). Financing Education - Investments and Returns: Analysis of the World Education Indicators 2002 Edition. Paris: OECD \& UNESCO.

PA Consulting Group (2002). Determining the Costs of Widening Participation: Report of Pilot Study. London: PA Knowledge.

Patrinos, H.A. (2000). Market Forces in Education. European Journal of Education, 35, (1) 6180.

Patrinos, H.A. \& Ariasingam, D.L. (1997). Decentralization of Education: Demand-Side Financing. Washington, D.C.: World Bank.

Patrinos, H.A. \& Psacharopoulos, G. (2002). Returns to Investment in Education: A Further Update. Policy Research Working Paper Series, . Washington, D.C.: The World Bank.

Psacharopoulos, G. (1994). Returns to Investment in Education: a Global Update. World Development, 22, 1325-1343.

Psacharopoulos, G. (2000). Economics of Education à la Euro. European Journal of Education, 35, (1), 81-95.

Reay, D., David, M. \& Ball, S.J. (2001). Making a Difference: Institutional Habituses and Higher Education Choice, Sociological Research Online, 5, (4), http://www.socresonline.org.uk/5/4.reay.html

Romer, P.M. (1990). Endogenous Technological Change. The Journal of Political Economy, II, (5), 71-102.

Ross, K.N. \& Levacic, R. (1999) (Eds.). Needs-Based Resource Allocation in Education. Paris: UNESCO Publishing. 
Sammons, P. (1999). School Effectiveness: Coming of Age in the 21st Century. Lisse: Swets \& Zeitlinger.

Sammons, P. (2002). Effective Schools, Improving Schools and Inclusive Schools. In C. Campbell (Ed.), Developing Inclusive Schooling: Perspectives, Policies and Practices (p. 120 149). London: Institute of Education, University of London.

Sammons, P., Hillman, J. \& Mortimore, P. (1995). Key Characteristics of Effective Schools: A Review of School Effectiveness Research. London: Ofsted.

Sammons, P., Thomas, S. \& Mortimore, P. (1997). Forging Links: Effective Schools and Effective Departments. London: Paul Chapman.

Schultz, T.W. (1961). Investment in Human Capital. The American Economic Review, 51, (1), $1-17$.

Teddlie, C. \& Reynolds, D. (2000). The International Handbook of School Effectiveness Research. London: Falmer Press.

Thomas, H. \& Martin, J. (1996). Managing Resources for School Improvement: Creating a costEffective School. London: Routledge.

Thrupp, M. (1999). Schools Making a Difference: Let's be realistic! Buckingham: Open University Press.

Tooley, J. (1995). Markets or democracy? A reply to Stewart Ranson. British Journal of Educational Studies, 43, (1), 21-34.

Tooley, J. (1996). Education Without the State. London: Institute of Economic Affairs.

Tooley, J. (2000). Reclaiming Education. London: Cassell.

TTA (2002). Qualifying to Teach: Professional Standards for Qualified Teacher Status and Requirements for Initial Teacher Education . London: Teacher Training Agency.

Vignoles, A., Levacic, R., Walker, J., Machin, S. \& Reynolds, D. (2000). The Relationship Between Resource Allocation and Pupil Attainment: A Review. London: DfEE Research Report No. 228.

Vila, L.E. (2000). The Non-Monetary Benefits of Education. European Journal of Education, $35,(1), 21-31$.

Whitty, G. (2002). Making Sense of Education Policy. London: Paul Chapman Publishing.

Whitty, G., Power, S. \& Halpin, D. (1998). Devolution and Choice in Education: The School, the State and the Market. Buckingham: Open University Press.

Wiseman, S. (1967). Children and Their Primary Schools. Volume 2. London: HMSO.

Wolf, A. (2002). Does Education Matter? Myths about education and economic growth. London: Penguin.

Woods, P. \& Levacic, R. (2002). Raising School Performance in the League Tables (Part 2): Barriers to Responsiveness in Three Disadvantaged Schools. British Educational Research Journal, 28, (2), 227-247.

World Bank (1995). Priorities and Strategies for Education: A World Bank Review. Washington, D.C.: World Bank.

Wright, S.P., Horn, S.P. \& Sanders, W.L. (1997). Teachers and Classroom Context Effects on Student Achievement: Implications for Teacher Evaluation. Journal of Personal Evaluation in Education, 11, 57-67.

Wylie, C. (1994). SelfManaging Schools in New Zealand: the Fifth Year. Wellington: New Zealand Council for Research.

Wylie, C. (1995). Contrary currents: the application of the public sector framework in education. New Zealand Journal of Educational Studies, 20, (2), 149-64.

Wylie, C. (1997). Self Managing Schools Seven Years On - What Have We Learnt? Wellington: New Zealand Council for Research. 


\section{Bildungsfinanzierung und die Verbesserung von Schulen: konzeptionelle Fragen und bildungspolitische Debatten im Vereinigten Königreich (United Kingdom)}

\section{Zusammenfassung}

Dieser Artikel fragt nach dem Verhältnis zwischen Bildungsfinanzierung und wichtigen bildungspolitischen Entscheiden, mit denen die Bildungsverwaltungen gegenwärtig konfrontiert sind. Er zeigt auf, wie sich Entscheidungen über Höhe und Verteilung der Ausgaben auf nationale Bildungssysteme, Bildungsinstitutionen und Studierende auswirken. Auf dem Hintergrund der Diskussion um Bildungsinvestitionen als soziale Investitionen macht der Beitrag auf einige spezifische bildungspolitische Überlegungen in neueren Versuchen, den Bereich der obligatorischen und nachobligatorischen Bildung zu verbessern, aufmerksam. Speziell von den britischen Erfahrungen ausgehend werden die Effekte von Ausgaben- und Finanzierungsentscheiden auf den Zugang zu Bildungsinstitutionen und die Leistung von Studierenden betrachtet. Wir folgern, dass Finanzierungsfragen nicht in rein technischer Art bearbeitet werden können, sondern von ideologischen Perspektiven über grössere ökonomische und soziale Prioritäten abhängig sind.

\section{Financement de l'éducation et amélioration scolaire : l'impact des choix conceptuels et des débats politiques en Grande Bretangne.}

\section{Résumé}

Cet article explore les articulations entre les modalités de financement de l'éducation et les choix politiques auxquels doivent faire face les gouvernements. Il montre comment les décisions concernant le niveau mais également la distribution des dépenses ont des impacts différenciés sur le système éducatif, les institutions scolaires et les élèves et étudiants. Après avoir présenté le concept d'investissement social dans l'éducation, l'article explore les enjeux politiques spécifiques attachés aux tentatives récentes d'amélioration de l'enseignement aux niveaux obligatoire et post-obligatoire. A partir de l'expérience britannique, l'article évalue l'impact des décisions relatives aux dépenses et aux mécanismes de financement sur l'accès et les performances du système éducatif. Nous montrons que les questions de financement ne peuvent pas être résolues en termes strictement techniques, mais que les orientations idéologiques, et leur influence sur les priorités économiques et sociales, doivent également être prises en compte dans l'analyse. 


\section{Finanziamento della formazione e innovazioni: modelli e dibattito politico in Gran Bretagna}

\section{Riassunto}

Quest'articolo esplora le articolazioni tra le modalità di finanziamento dell'educazione e le scelte politiche che devono affrontare i governi. Esso mostra come le decisioni riguardanti il livello e la distribuzione delle spese hanno degli impatti differenziati sul sistema educativo, le istituzioni scolastiche e gli allievi e studenti. Dopo aver presentato il concetto d'investimento sociale nell'educazione, l'articolo discute alcune considerazioni politiche specifiche, legate ai recenti tentativi di miglioramento dell'insegnamento a livello obbligatorio e post-obbligatorio. A partire dall'esperienza britannica, l'articolo valuta l'impatto delle decisioni relative alle spese e ai meccanismi di finanziamento sull'accesso e sui risultati del sistema educativo. Concludiamo dicendo che queste questioni non possono essere risolte in termini prettamente tecnici, ma che vanno presi in considerazione anche gli orientamenti ideologici e la loro influenza sulle priorità economiche. 
T h e m a 